\title{
揖斐川高水敷掘削後の微地形形成過程 MICROTOPOGRAPHY FORMATION AFTER FLOOD-CHANNEL EXCAVATION IN IBI-RIVER
}

\author{
原田守啓 1 - 永山滋也 2 - 大石哲也 1 ・萱場祐一 3 \\ Morihiro HARADA, Shigeya NAGAYAMA, Tetsuya OISHI and Yuichi KAYABA \\ 1正会員 博（工）（独）土木研究所 水環境研究グループ 自然共生研究センター \\ （干501-6021 岐阜県各務原市川島笠田町官有地無番地）

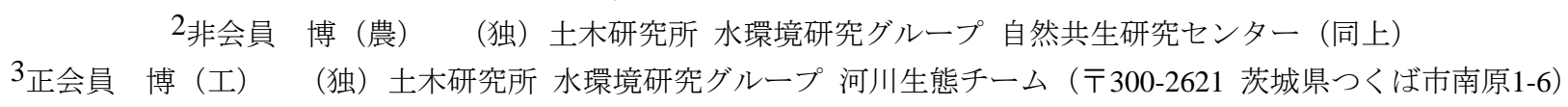

\begin{abstract}
Flood-channel excavation is not only countermeasure against river flooding but also effective operation for floodplain restoration. In the Ibi River, 14 excavation sites varying in relative height to water level were investigated to examine process of microtopgraphy formation after the flood-channel excavation. Deposit rate was lower in the sites with lower relative height. The proportion of water area (i.e. floodplain waterbodies) in the excavation sites was $10-20 \%$. Sediment profiles were also surveyed at 10 locations in two representative sites and were elaborated in relation to microtopographies that were classified into four types: natural-levee, low land behind natural-levee and isolated and connected waterbodies. Moreover, the microtopography formation process and factors were estimated based on the results of the field survey.
\end{abstract}

Key Words : floodplain restoration, channel excavation, microtopography, backwater, natural-levee

\section{1. はじめに}

洪水流下能力の向上を目的とし，河積を拡大するため の高水敷掘削が全国各地の河川で計画・実施されている. また，高水敷掘削と同時に，ワンド・たまりといった汇 濫原的な環境を河道内に創出する試みも行われつつある.

原生的な汇濫原は，生態学的な生産性と多様性が非常 に高い場である1)ことが知られている. 自然堤防帯（セ グメント2）を流下する河川は，自然状態であれば，広 大な汇濫原を伴うものであるが，我が国の沖積平野では， 近世以降の河道改修と築堤によって後背湿地に汇濫が及 ぶ頻度は激減し，“洪水時に冠水する土地”である広義 の汇濫原は，河道内に狭く限定されている．河道内の氾 濫原は，面積的に狭いだけでなく，連続的な高水敷の造 成と低水路の浚渫による河道の複断面化が進められ，よ り人工的になってきている2).さらに，上流域からの土 砂供給の減少や砂利採取等に伴う河床低下により，河道 内の水域と陸域の比高差が拡大した結果，比較的自然度 が高い状態で残された高水敷・砂州の樹林化が進行し， 河道内汇濫原が質的に劣化しつつある河川も見られる ${ }^{3)}$. このような状況にあって, 河積の確保を目的とした高水 敷の掘削は，比高が高い土地を人為的に切り下げる操作 であることから，汇濫原的な環境の創出と両立できる可
能性が高い行為であり，可能であれば汇濫原的な環境を 積極的に創出することが望ましい.

高水敷掘削によって河道内に汇濫原的な環境を創出す るためには，いくつかの技術的課題が指摘される。まず， 河積拡大を目的とした場合とは，望ましい姿が必ずしも 一致しない点である. 治水目的の高水敷掘削では，洪水 の流れを妨げない平滑な地形が掘削後に長く維持される ことが望ましい. 一方, 汇濫原的環境の創出を目的とし た高水敷掘削では，ワンド・たまりといった汇濫原に特 徵的な水域とそれを取り巻く微高地が入り組んだ多様な 環境が形成・維持されることが期待される.なぜならば， 原生的な汇濫原の高い生態的機能は, 多様な地形要素に より支えられている4ためである.

このため, 高水敷掘削において汇濫原環境を創出する ためには，汇濫原的な環境が長く維持される地形を当初 から整備するか, 河川の営力によって形成させるか, い ずれかのアプローチを選択する必要が生じる.いずれの アプローチを採るにせよ, 掘削後の地形変化を予測する 技術が必要である．また，地形変化の予測を踏まえて， 氾濫原環境の再生適地の抽出や，最適な掘削方法等の検 討がなされるべきである．河道内の地形変化の予測は， 平面二次元河床変動解析によってなされることが一般的 であるが，解析の空間解像度はメッシュサイズに依存し 


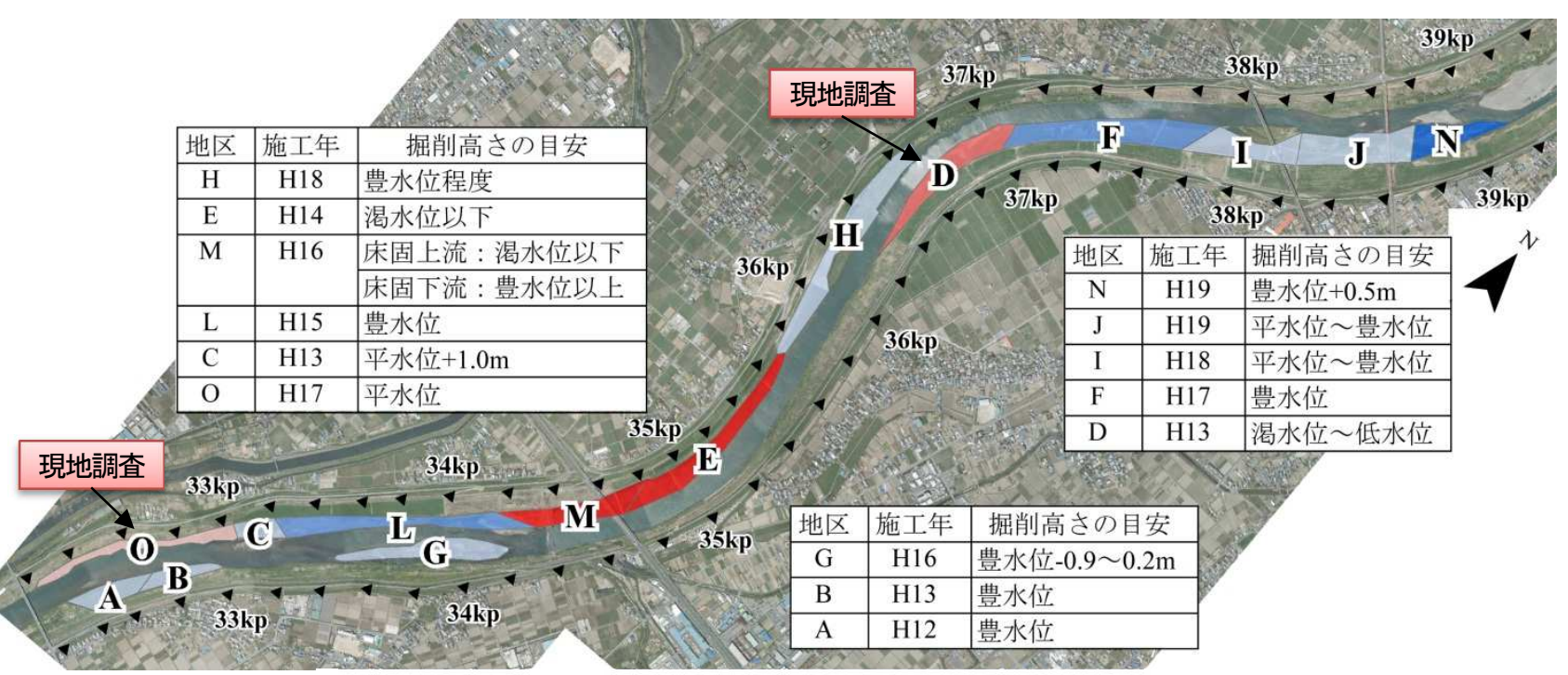

図-1 調査区間及び高水敷掘削箇所一覧（木曽川水系揖斐川）

ており, 規模の大きい河川地形の変化や，大まかな侵 食・堆積傾向を平面的に把握寸ることはできても, メッ シュサイズよりも詳細な地形の表現は困難である. 高水 敷掘削後の地形を含む環境の変化を予測する手法を構築 するためには，掘削後に生じている事象の分析が，まず 必要であると考える.

そこで本研究は, 高水敷掘削において汇濫原的環境を 創出するための工学的な知見を蓄積するため, 木曽川水 系揖斐川をケーススタディとして, 掘削後に土砂が再堆 積する過程で現れる微地形の形成過程に着目した現地調 査を行った．また，現地調査結果を踏まえ，特徴的な微 地形の形成プロセスと, ワンド・たまり等の汇濫原的水 域の関係について整理した．以上を踏まえ，高水敷掘削 後の地形変化を河床変動解析等により予測しようとする 際の留意点を検討した.

\section{2. 調査手法}

\section{（1）調査区間の概要}

調查区間は，木曽川水系揖斐川32～39k区間である

（図-1）。当該区間では，国土交通省木曽川上流河川事 務所が，主に河積の拡大を目的としてH12年度からH19 年度にかけて低水路に面した高水敷の掘削を実施してい る. 施工年度及び掘削高さの設定が異なる工区毎にそれ ぞれA〜O地区と名付け，モニタリングを実施している，

調查区間の河床勾配は約1/3300程度であるが，区間上 流端付近が河床勾配約 $1 / 1700$ 程度の区間との勾配変化点 にあたり, 低水路流心部の河床材料は区間内で大きく変 化する. 区間上流側では，粗砂・細砶が主体であるのに 対し，下流側では細砂・中砂が主体となっている.

河道内の植物群落は, 河川水辺の国勢調査より, セイ タカアワダチソウ群落, オギ群落, ヤナギ類（アカメヤ ナギ，ジャヤナギ，タチヤナギ，カワヤナギの 4 種）が 多く見られている.

\section{(2) 調查手法}

\section{a）掘削後の出水履歴, 地形変化及び植生遷移}

国土交通省水文水質データベースから，調查区間の上 下流に位置する万石観測所(40.6k)及び今尾観測所(27.0k) の観測記録を収集し，出水履歴を把握した．また，掘削 前後の定期縦横断測量, 空中写真等から, 掘削後の堆積 傾向を把握した. また, 河川水辺の国勢調査結果より, 植物群落の遷移について把握した。

\section{b）堆積物調査（柱状図及び各層の粒度組成）}

掘削後に再堆積した堆積物の鋁直構造と粒度組成を把 握するため, 高水敷掘削後に再堆積した層の状況と各層 のサンプリングを現地作業で行い，持ち帰ったサンプル について土質粒度試験を行った。調査地点は，a）の調査 結果を踏まえ, 渴水位から平水位の高さで掘削した 2 地 区（D地区，O地区）に対象老絞り, 河道の平面形状と 低水路からの距離を考慮して，10地点を設定した．現地 調查は，平成26年2月上旬に実施した.

\section{c) ヤナギ類の生育状況}

ヤナギ類は河川における代表的な先駆植物であり，平 水面より低く掘削した箇所に現在生育しているヤナギ類 は, 土砂の堆積によって水面よりも高い裸地が形成され た時期を示寸指標になりうると考えられる. そこで，堆 積物調査を実施した10地点の付近において，ヤナギの樹 高、胸高直径及び胸高の年輪数を記録した. サンプル数 は各地点 $\mathrm{N}=5$ or 6 とし, 計55サンプルのデータを得た.

\section{3. 調査結果と考察}

\section{（1）出水履歴と流況}

調査区間上流に位置する万石水位観測所のH13 H22 の10年間の観測值より, 出水履歴及び位況を把握した. 期間中の平水流量は $48 \mathrm{~m}^{3} / \mathrm{s}$, 平均年最大流量は $2160 \mathrm{~m}^{3} / \mathrm{s}$ であった．洪水ピーク流量及び発生時期を整理した結果 を図-2に示寸，なお，ピーク流量の閾値は，試行的に $500 \mathrm{~m}^{3} / \mathrm{s}$ として，これを上回る出水のみを表示した. 
掘削計画立案時に掘削高さの拠り所とされた豊平低渴 水位は, $\mathrm{H} 1 \sim \mathrm{H} 11$ の万石水位観測所の位況の平均值を もって設定されたが，H13〜H22各年の豊平低渇水位に はかなりばらつきがあり, 豊水位は最も振れ幅が大きく, 年によって $50 \mathrm{~cm}$ 程度の差があった。

\section{（2）掘削後の堆積状況の概況}

H14,H17,H20に実施された3回の測量成果に基づき， 各工区の掘削箇所に該当寸る測線の横断図から，各工区 の掘削面における河床変動量を整理した（図-3）。これ らの変動量には，掘削工事による負の変動量も含まれて いる．施工時期と測量時期のタイミングにより， 3 グ ループに分けて示した. グループ1は，H14測量以前に 施工された地区であり，H14-H17，H17-H20は掘削後の 変動量を示す．グループ2はH14とH17の測量の間に施工 されたもので, H17-H20が掘削後の変動量を示す．グ ループ3は，H17とH20の測量の間に施工されたもので, 掘削後の変動量は把握できていない.

図-3のグループ1と2について，堆積速度(m/年)を試算 した結果と地区毎の掘削高さの関係を図-4に示す．グ ループ1についてはH14-H17の值，グループ2については H17-H20の変動量を用いた. 図-4にはやや右上がりして 頭打ちする傾向がみられ，堆積速度には掘削高さが関係 している可能性がある. なお, Hori et.al. ${ }^{5}$ は, 35.4kp左岸 の堤内地で, 旧河道の自然堤防及び後背湿地における堆 積速度をボーリングコアから推定しており, 後背湿地堆 積物の堆積速度は $0.1 \sim 0.2 \mathrm{~cm} /$ 年, 自然堤防堆積物は約 $1.5 \mathrm{~cm} /$ 年と推定している. 河道内の高水敷掘削面におけ る堆積速度は, 旧河道における堆積速度と比べて, 1 オーダー程度大きいようである。

\section{（3）地被及び開放水面の面積割合の変化}

大石らの゙が，H13,H19,H24の河川植生図を用いて植物 群落の推移を分析した結果によれば，掘削前後の植物群 落の変化傾向には, 掘削高さによる違いが明瞭に確認さ れている. 図-5に，掘削高さの設定と，掘削範囲におけ る地被及び開放水面の面積割合を示す，掘削工事はH12 からH19の間に行われていることから，概ねH13が工事 前, H19及びH24が掘削後の変化を示している.

渴水位程度で掘削した工区は，H24に面積の84\%が開 放水域として維持された。これらの水域は，本川水路と 連続した低水路の一部として大部分が維持されており, 図-4に示寸堆積速度が小さいことと傾向が一致している. 一方，低水位から豊水位で掘削した工区では，開放水面 は約10〜20\%見られる.これらは本川と接続したワンド, 独立したたまり，または低水路の水面の一部として残存 している. 汇濫原的な環境の創出を目的とした高水敷掘 削では，これらの水域が長期間安定して維持されること が望ましく，この形成・維持機構に着目する必要がある. 低水位から豊水位で掘削した工区は, 切り下げ後にヤ

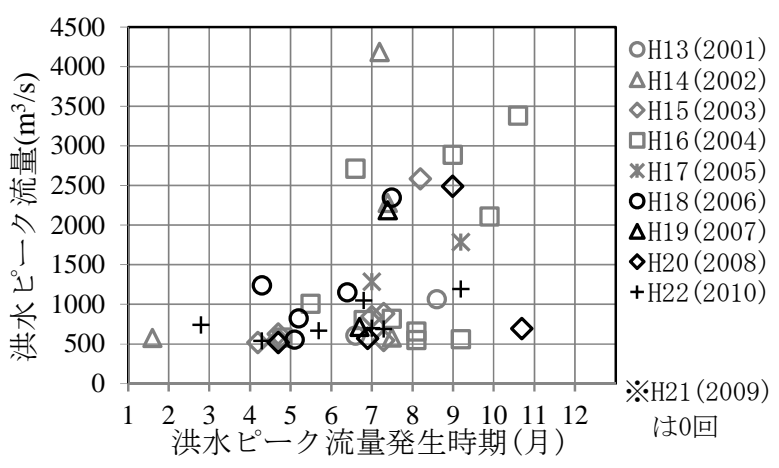

図-2 洪水ピーク流量及び発生時期（万石観測所）

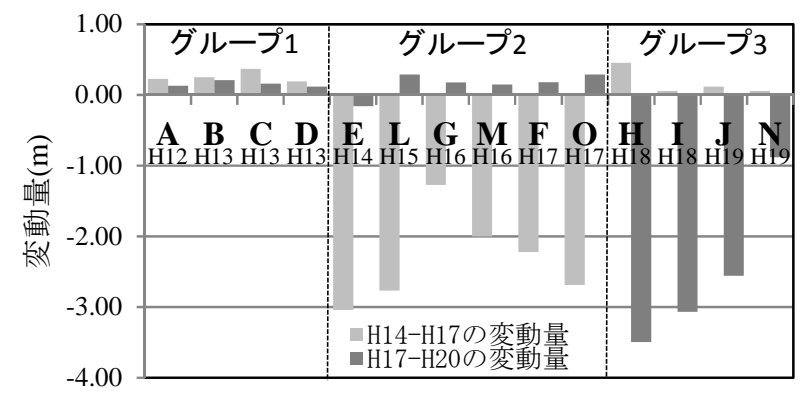

図-3 各地区の平均的な河床変動量

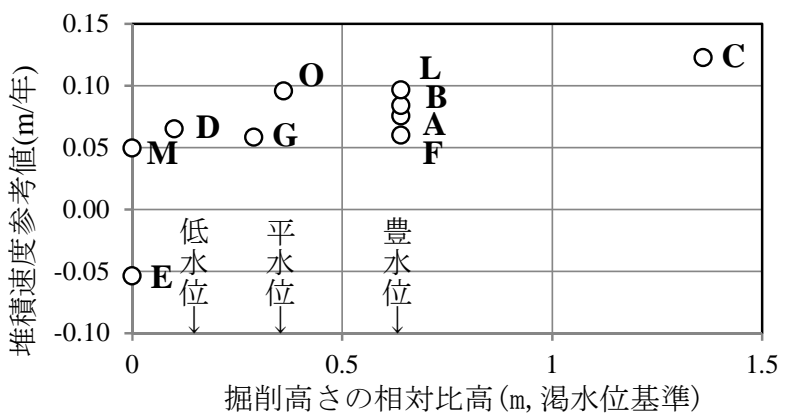

図-4 堆積速度(参考値)と掘削高さの関係

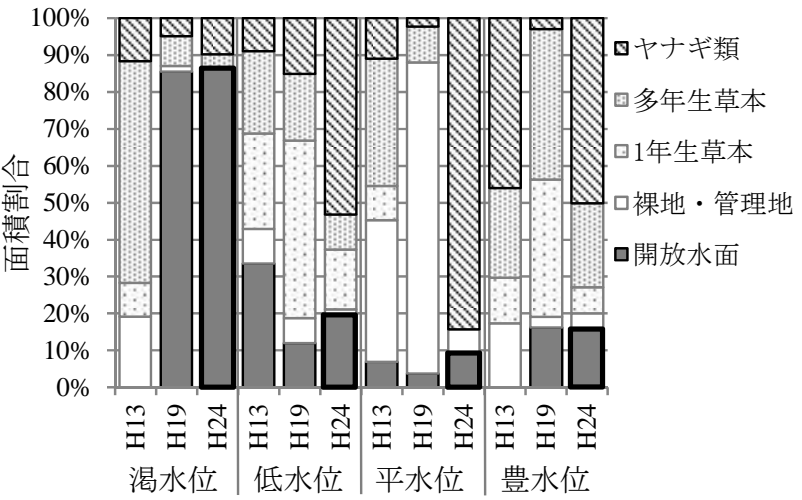

図-5 掘削高さと開放水面を含む地被面積割合の変化

ナギ類が侵入・定着している割合が高い. とくに，平水 位で掘削した工区では，H19に大部分が裸地であったの が，H24にはヤナギ類に覆われており，短期間にヤナギ 類が侵入・定着したことが確認される. ヤナギ類の種子 の発芽能力は種子の散布後の短期間（2週間程度）に限 られており, 土壤・水分条件が適している必要がある7. 調査区間では, 掘削後の裸地において, 土砂堆積や水位 変動の過程で，定着しやすい条件が整ったと考えられる.

\section{（4）調査地の景観と特徵的な微地形}



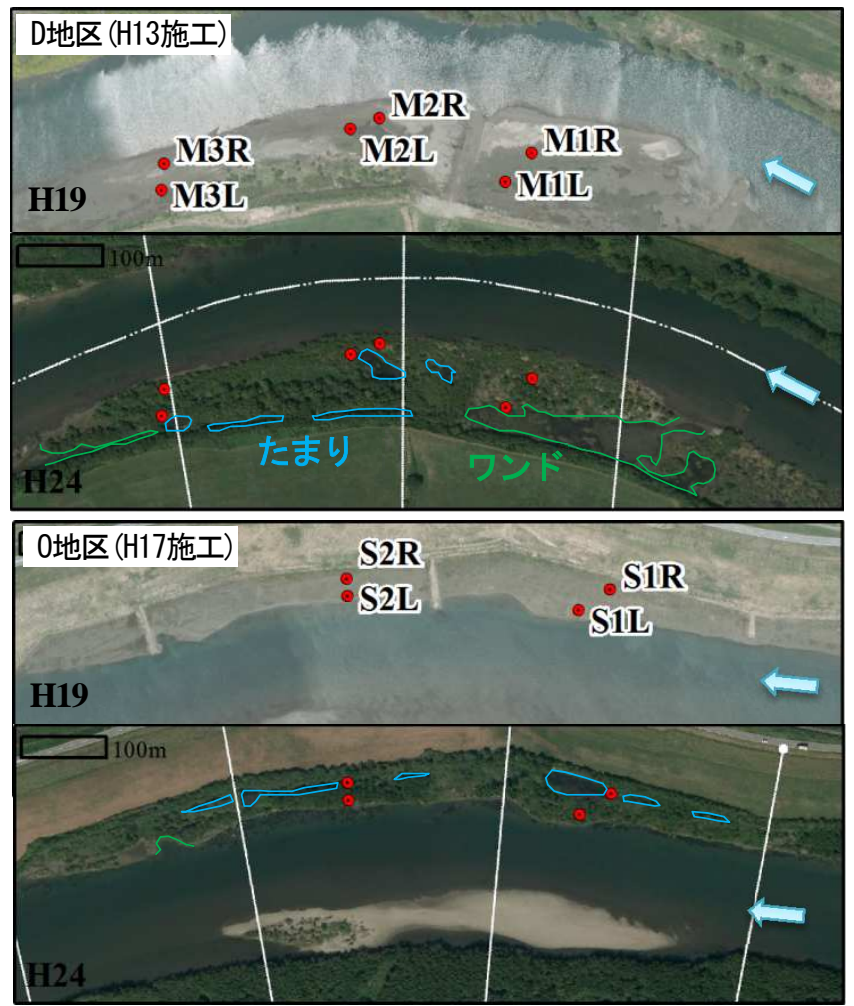

図-6 現地調査地点位置と空中写真 $(H 19, H 24)$

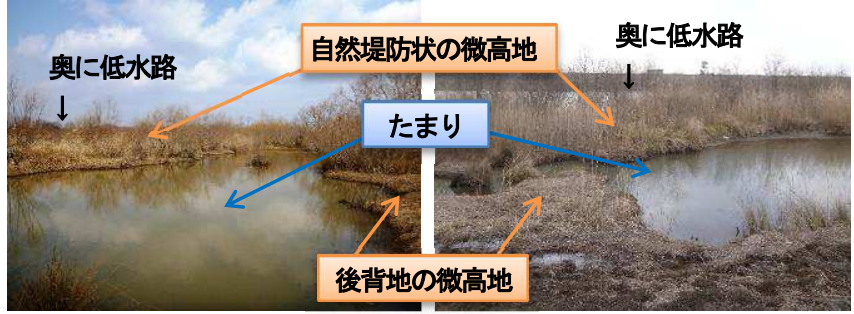

写真-1 調査地の景観(左:M2L付近, 右:S1R付近)

現地調查を実施した，D地区，O地区の空中写真を図一 6に示寸. 両地区とも掘削後に土砂の堆積が進み, 主に ヤナギ群落に覆われている．湾曲部内岸に位置するD地 区では，上流側の大きなワンドと形状が異なる複数のた まりが確認される，直線部あるいは緩い湾曲部の外岸に 位置するO地区には，細長いたまりが複数確認される.

両地区の景観を，写真-1に示寸。両地区に共通してみ られる特徵的な微地形として, (1)自然堤防状の微高地,
(2)後背地の微高地，低水路水面に接続している(3)ワンド, 微高地に囲まれた(4)たまりの4種が確認された. (1)自然 堤防状の微高地は, 低水路水際に沿って幅数 $\mathrm{m}$ 程度の微 高地が直線的に連続している. 一方，(2後背地の微高地 は，(1)よりも低く平坦で，複雑な平面形状を有している のが特徵的である.

\section{（5）堆積物の内容と特徵的な微地形の対応}

より詳細な堆積状況と微地形の形成過程を把握寸るた め, 湾曲部内岸に位置するD地区 $(\mathrm{H} 13$ 施工，渇水位～平 水位で掘削), 直線部のO地区(H17施工，平水位で掘削) の堆積状況を調査した. 調査地点は, 図-6に示すとおり であり，水際とその後背地の2地点1組で設定した。

図-7に各調査地点の堆積物の簡易柱状図を示寸，2地 点1組として, 水際の地点を左, 後背地の地点を右に示 す。高水敷掘削工事の時点で, 締め固まったシルト層が 河床に露出したことが確認されている. 本調査において も，堆積層を掘り進む際に，上部の堆積層とは明らかに 異なる締め固まったシルト層を確認した．VRS-GPS測 量により標高を計測した上で基盤層と判断した．基盤層 の高さにほとんど変化はみられなかった.

掘削後に堆積した層は，5組全てにおいて，低水路に 近い水際の地点の方が, より高く堆積しており, 現地で は自然堤防状の微高地を認めることができた. ただし， 下流側に向かって，その比高差は縮まる傾向があり，下 流側では自然堤防状の高まりが不明瞭となる.

武内ら ${ }^{8}$ は, 川内川における掘削後の再堆積過程を詳 細に分析し，堆積の生じ方を河川横断面形状に注目して， 自然堤防状に堆積寸る「河岸際凸型」と一様に堆積寸る

「一様堆積型」に区分した．また，この違いが，出水時 の低水路と高水敷の水深比と, 砂州上流端からの距離に より区分される傾向を示した．調査結果は概ねこの知見 と一致するが，図-7に示されるとおり，流送土砂の粒度 分布が広い本調査地では，堆積過程で平面・鉛直方向の 分級が生じており，やや複雑なようである.

自然堤防状の微高地の堆積物に着目寸れば，M1Rが砂

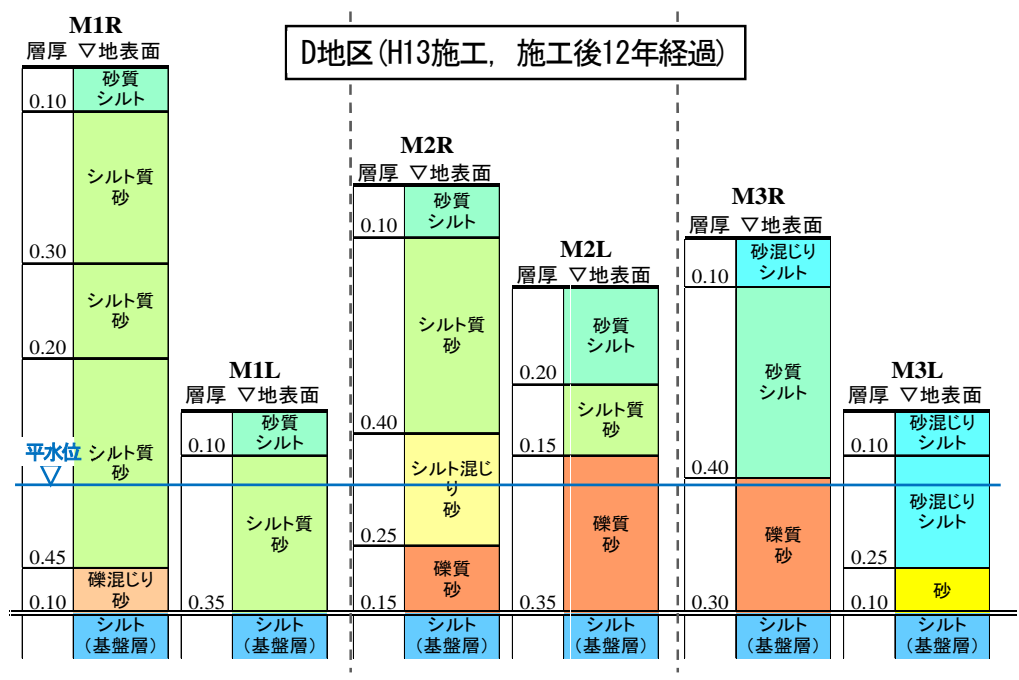

図-7 高水敷掘削後の堆積物調査結果 柱状図

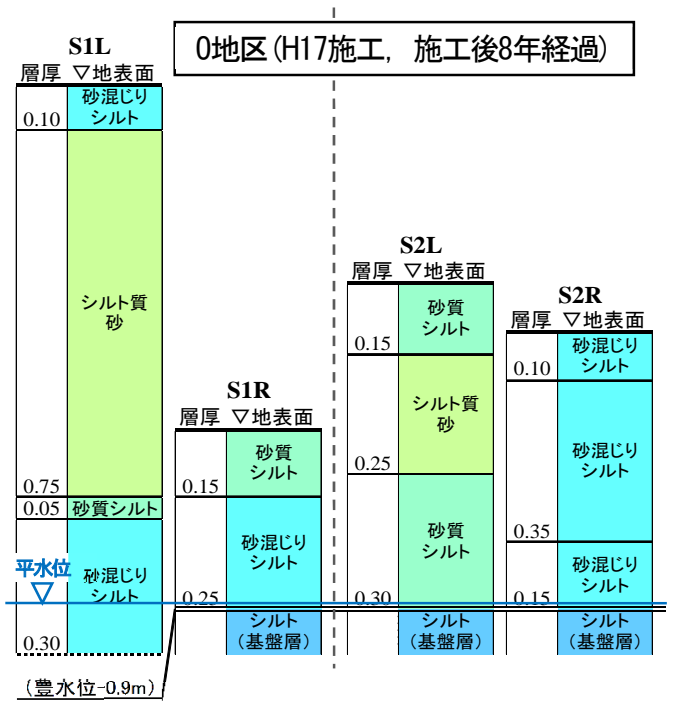


主体であるのに対し，M2R,M3Rと徐々にシルト主体と なっていって, 縦断的に構成粒度が小さくなっている. ただし，M2からM3の基盤層の直上には，中磎・細碩を 含む層が最大 $35 \mathrm{~cm}$ 堆積しており, 堆積の初期に粒径の 大きい土砂が基盤層上を流下したことが確認できる（図 -6, H19の写真に帯状の堆積地形が確認される）。図-2 によれば，M1からM3が位置するD地区が掘削された直 後のH14に期間中最大の出水が発生しており, これらの 磎質砂はこのときに堆積したものと考えられる.

\section{（6）ヤナギ類の定着時期の推定}

図-6に示すD地区，O地区におけるヤナギ類の定着時 期を考察するため, 調査データ計 55 サンプルの年輪数 データに着目した，全体では，年輪数 6 本が最も多く (25/55), 次いで5本(14/55)であった. H13に施工したD地 区とH17に施工したO地区で，年輪数に統計的に有意な 差はなく(p>0.05), 両地区へのヤナギ類の定着は概ね同 時期に起こったと考えられた. ただし, 両地区とも, 自 然堤防状の微高地と，後背地の微高地を比べると，自然 堤防状の微高地の方が平均の年輪数が多い傾向があった。

調査地では土砂堆積が進んでいること, ヤナギが出水 等の攪乱を受けており，倒伏・萌芽等の状況が見られた ことから，実際の樹齢は年輪数よりは多いと考えられる. O地区がH17施工であることと年輪調查結果から, ヤナ ギ類の定着時期は両地区共にH18又はH19 と推定された。

\section{4. 微地形形成プロセスの推定}

本調査地における高水敷掘削後に土砂が再堆積する過 程で形成された微地形として, (1)自然堤防状の微高地, (2)後背地の微高地, 自然堤防状の微高地の背後の(3)ワン ド，微高地に囲まれた(4)たまりの4種が確認された。こ れらの微地形の形成過程を, 総合的に考察寸れば以下の ようである. また，これらのまとめを図-8に示す。

\section{（1）微高地の形成による水域と陸域の分化}

現在の水際に見られる自然堤防状の微高地(1は，主に 粒径 $0.1 \mathrm{~mm}$ 程度の微細砂から成る. 一方, 後背地の微高 地(2)堆積物は粒径 $0.01 \mathrm{~mm}$ 程度のシルトが主体である。 これらの空間分布の特徵は, 藤田 ${ }^{9}$ が解析結果に示した 微細砂とシルトの堆積速度の横断分布の傾向と良く一致 している. 調査地点M2，M3の掘削面上には，大規模な 出水によって掃流砂として流下・堆積したと考えられる 砂碩も堆積しているが，堆積物の大部分は，中小出水に よっても浮遊砂として運搬されうる細粒分である。また, 本調査地の掘削面は低く, 中小出水によっても長時間冠 水する状況にあったことから，これらの微高地の形成は 広い幅の流量の下で進んだ可能性がある。また，ヤナギ 類の年輪数は(2)よりも(1)の方が多い傾向があり, 自然堤 防状の微高地(1)の方がより大きい速度で堆積し, 先に陸

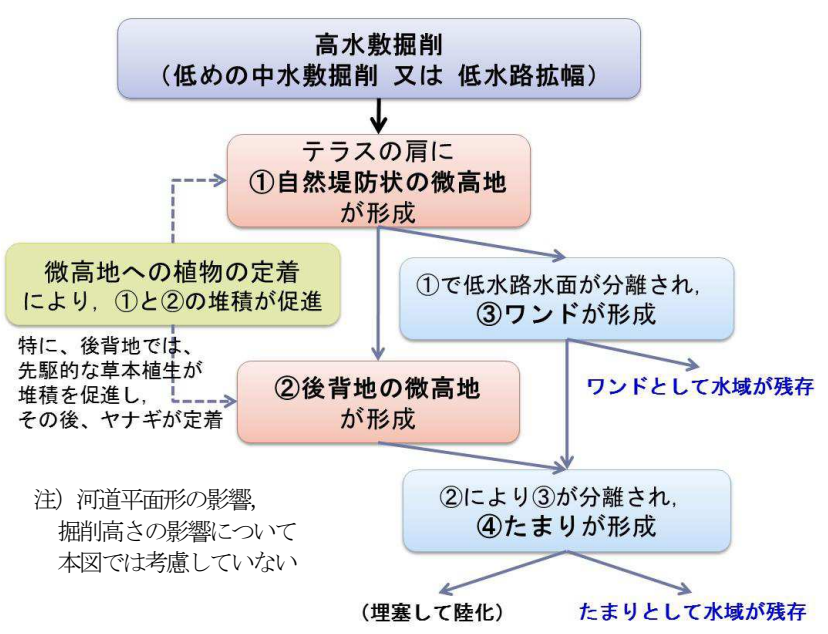

図-8 本調査地において推定される微地形形成過程

域化したことが示唆される. 自然堤防状の微高地(1)゙低 水路との境界に発達し, 低水路と後背地の水域が分離さ れ, 植物が定着した結果, 低水路から後背地一の土砂の 流入がより制限されると考えられる.これらのことから， 自然堤防状の微高地(1)，その背後に位置する汇濫原的 水域の形成と維持に深く関わっている可能性がある.

これらを整理すると, 自然堤防状の微高地(1)が発達寸 ることにより，低水路と連続した開放水面が隔てられる ことによってワンド (3) が形成される. 微高地(1)の後 背地側のシルトを主体とした微高地(2)が発達して陸域化 することによってワンドの埋塞と分離が進み，たまり

(4)）が形成されたと考えられる.

\section{（2）微高地の形成における植物の影響}

(3)ワンド，(4)たまりの水際線は，島状，半島状の複雑 な平面形を持つ微高地(2)よって縁どられている．微高 地(2)では, 堆積土砂のかなり深い層から, 草本類の根茥 や葉が埋没した状態で見つかっている. また， ワンド・ たまりの浅い水域には，イグサ科植物が抽水した状態で 点在して見られる. 水際には, タデ類, イネ科植物が繁 茂している.これらの, 湿性の環境に適応している先駆 的な草本植生が，ヤナギ類が定着するより以前の，地盤 高が平水位より低い状態における土砂の堆積に寄与して いる可能性が示唆される. 藤田ら ${ }^{9}$ は, 植生がウオッ シュロードの捕捉・堆積に及ぼす効果を仔細に検討し, 低水路拡幅後の高水敷形成のシナリオに, 部分的な植生 繁茂が強く関与することを提示している. 本調查地に見 られる微高地(2)の形成においても, 先駆的に定着した草 本植物を介して同梯の堆積機構が作用し, 水域と陸域の 分化が助長された可能性が高い. 抽水状態で点在してい る草本植物がパッチ状に土砂を堆積させたと仮定すると, 微高地(2に植物が埋没していること, 複雑な平面形を有 していることなどがうまく説明できる.

\section{（3）考慮すべきその他の要因}

a) 出水時の平面流況 - 局所的な流況との関係

湾曲部内岸に位置するD地区では，内岸の洲の上流側 
に上流側開放型ワンド，洲の下流側に下流側開放型ワン ドが見られる（図-6）．複断面河道の湾曲部を洪水流が 流下寸る際，流線が内岸側をショートカットするように 流れることは良く知られており，D地区のワンドが維持 されている一つの要因として考えられる. 湾曲部と直線 部は出水時の流況が異なり，このことが高水敷掘削後の 堆積形状に与える影響に留意しなくてはならない.

また，現地のたまりの中には，出水時の局所的な流況 によって，土砂堆積や植物の定着が抑制されていると考 えられる箇所も存在する．低水護岸に沿った細長いたま り（図-6; 高水敷沿いに線状に分布）や，水制等の周辺 の局所洗掘によって保持されているたまり等である.こ れらの事象については, 別途整理が必要と考えられる.

\section{b) 掘削高さとの関係}

図-8は，調査地2地区の状況はよく説明しうると考え られるが，他地区には上手く説明できない状況もみられ る. 例えば，図-5に示寸豊水位以上の高さで掘削した地 区に，たまりが形成・維持されている機構はおそそらく異 なる. たまりが干上がらずに維持されるためには, 河川 表流水，天水，湧水のいずれかに依存せざるを得ない。 豊水位以上の高さに存在するたまりは，湧水及び天水一 の依存性が高い状態で維持されている可能性が高い.

\section{c）本事例の位置づけ}

自然堤防帯における高水敷掘削が各地で実施されてい る中での本事例の位置づけを整理しなくてはならない. 揖斐川は, 高水敷掘削後の基盤に後背湿地堆積物由来の シルト層が露出し，その後，シルトを主体とした土砂が 再堆積する経過を辿った. 掘削後の河床材料, 堆積・侵 食傾向は，河川によって異なると考えられ，全国で実施 されてきた高水敷掘削の事例について広範な調查を実施 した上で, 何らかの類型化が必要であると考えられる.

\section{5. おわりに}

本研究のまとめを以下に示す.

- 揖斐川の高水敷掘削後の堆積速度には, 掘削高さとの 関係性が認められた．水位に対して低く掘削した箇所 の方が，平均的な堆積速度が小さい傾向が認められた。 ・高水敷掘削後に再堆積する過程で形成された微地形々 して, (1)自然堤防状の微高地, (2)後背地の微高地, 微 高地に囲まれた(3)ワンド，(4)たまりを確認した。

・微高地(1)と微高地(2)では, 堆積物の粒度組成が異なり, 平面位置による違いも認められた。しかしながら，ヤ ナギ類の年輪調查により, (2)より (1)のヤナギ類の方が 年輪数が多く, 早く定着したことが示唆された.

・現地調查結果より, 自然堤防状の微高地(1), 後背地の 微高地(2)の形成により, 水域が分離し, (3)ワンド, (4) たまりが形成された過程が推定され, 微高地(2)の形成 に, 先駆的な草本植物の関与が示唆された. 以上を踏まえ, 高水敷掘削後の地形変化を河床変動解
析等で予測する上での留意点を整理する，まず，広い流 量レンジが考慮される必要がある. 多量の掃流砂が堆積 するような出水イベントが存在する一方, 堆積物の大半 は中小出水によっても運搬されうるシルトである. 次に, 植物の影響を考慮できることである，植物は浮遊砂の堆 積が促進されるだけでなく, 平面的に複雑な微高地の形 成に関与している可能性が指摘される. さらに, 幅数m の自然堤防状の微高地，高水敷沿いの線状のたまりなど を表現するには，少なくとも同程度の空間解像度は必要 となる.これらの現象を考慮すべく,メッシュサイズを より細かく設定したとしても, 掘削後の出水, 土砂堆積 及び植物の相互作用によって形成される微地形の形成と 遷移を正確に予測することには，不確実性が伴うと考え られ，これを補う工夫が必要と考えられる。

本研究は, 高水敷掘削後の地形変化のみを扱った. し かしながら，ワンド・たまりを作ることのみを目標とす るのではなく, 生態学的に好ましい汇濫原的環境の目標 像が必要である.どのような状態にあることが望ましい のか, 生態学的見地から, 別途検討が必要である.

謝辞 : 本研究にあたり，国土交通省木曽川上流河川事務 所より各種資料を提供いただいた，記して謝意を示す。

\section{参考文献}

1) Tockner K., \& Stanford J.A. : Riverine flood plains: present state and future trends., Environmental Conservation, vol.29: pp.308-330., 2002.

2) 永山滋也，原田守啓，萱場祐一：セグメント2区間における 河道タイプと 氾濫原水域・指標生物分布との関係，土木技 術資料，vol.55-9, pp.6-9.,2013.

3) 根岸淳二郎, 萱場祐一, 佐川志朗 : 汇濫原の冠水パターン の変化とその生態的な影響〜淡水性二枚貝の生息状況の観点 から，土木技術資料，vol.50-11, pp.38-41., 2008.

4) Robinson C.T., Tockner K., \& Ward J.V. : The fauna of dynamic riverine landscapes., Freshwater Biology, vol.47, pp.661-677., 2002.

5) Hori, K., Usami, S., \& Ueda, H.: Sediment facies and Holocene deposition rate of near-coastal fluvial systems : An example from the Nobi Plain , Japan. Journal of Asian Earth Sciences, 41(2), pp.195203., 2011.

6) 大石哲也, 萱場祐一 : 河川敷切り下げに伴う初期条件の違 いが植生変化に及ぼす影響に関する一考察, 環境システム研 究論文発表会講演集, vol.41,pp.351-356., 2013.

7) 奥田重俊, 佐々木寧 : 河川環境と水辺植物-植生の保全と管 理-, pp.116-139., ソフトサイエンス社, 1996.

8) 武内慶了, 服部敦, 藤田光一, 佐藤慶太 : 細粒土砂堆積に よる高水敷形成現象を 1 次元河床変動計算に組み込んだ河積 変化予測手法，河川技術論文集，第17巻,pp.161-166., 2011.

9) 藤田光一, John A. Moody, 宇多高明, 藤田政人 : ウォッ シュロードの堆積による高水敷の形成と川幅縮小, 土木学会 論文集, No.511/II-37, pp.47-62, 1996.

(2014.9.30受付) 